\title{
Functional Disability
}

National Cancer Institute

\section{Source}

National Cancer Institute. Functional Disability. NCI Thesaurus. Code C132289.

An impairment that causes an individual to require assistance in order to perform an activity. 